
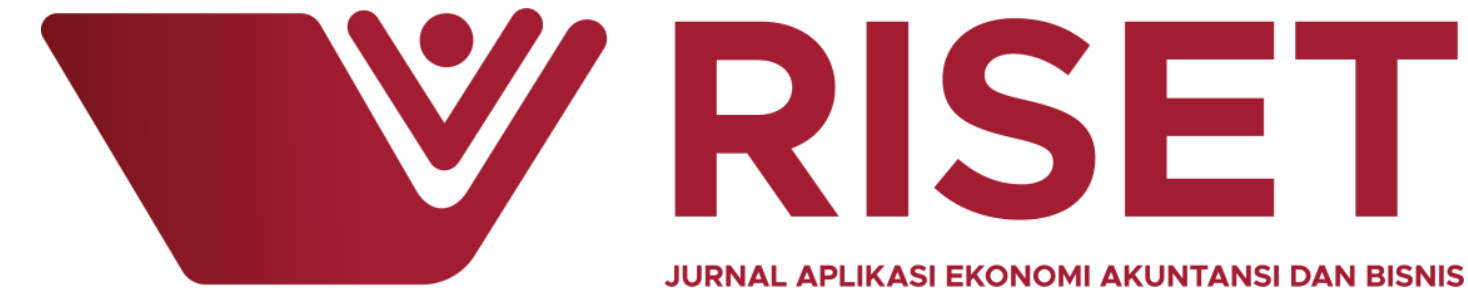

JURNAL APLIKASI EKONOMI AKUNTANSI DAN BISNIS

\title{
Pengaruh Iklan dan Endorser terhadap Brand Awareness serta Dampaknya pada Keputusan Pembelian
}

\author{
Budi Setiawan ${ }^{1)}$, Celia Celesta Rabuani ${ }^{2)}$ \\ ${ }^{1,2)}$ Program Studi Manajemen STIE Kesatuan Bogor
}

https://doi.org/10.35212/277621

\section{INFO ARTIKEL}

Pengaruh Iklan dan Endorser terhadap Brand Awareness serta Dampaknya pada Keputusan Pembelian

Submitted: 14 JANUARI 2019 Revised: 25 FEBRUARI 2019 Accepted: 18 MARET 2019

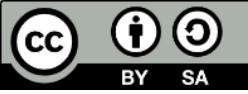

\begin{abstract}
The aim of this research is to analyze the influence of brand and endorser to brand awareness and its impact to purchase decision. The authors try to fulfill the research gap that exist, i.e. combining the brand and endorser in order to predict the brand awareness, that in our best knowledge still has less attention from researchers. Research samples a number of 100 respondents, were selected through nonrandom sampling technique, i.e. purposive sampling. Survey method was selected with questionnaire as a tool to gain primary data.

Based on the path analysis results that has ben conduct, it's revealed two sub-structure path equation $\hat{Y}=0,585 X_{1}+0,229 X_{2}$ and $\hat{Z}=0,237 X_{1}+0,108 X_{2}+0,510 Y$. Both brand and endorser, it's significantly proven influencing of the brand awareness. The consumer purchase decision significantly formed by the brand awareness as the antecedent that formed by brand and endorser. This research revealed a gap that need to be revised in the next research. Endorser failed to become antecedent of consumer purchase decision. So it will be need a better measurement, to make sure that consumer purchase decision were also can be formed by endorser.
\end{abstract}

Keywords: brand, endorser, brand awareness, consumer's purchase decision

E-mail:celia.celesta96@gmail.com ${ }^{11}$,budisetiawan@stiekesatuan.ac.id ${ }^{2)}$

\section{PENDAHULUAN}

Perkembangan teknologi dan informasi saat ini telah berlangsung sangat cepat dan dinamis, mengubah berbagai perilaku konsumsi belanja masyarakat. Salah satu indikasinya adalah semakin massive-nya keberadaan toko online yang memberikan banyak pilihan dan kemudahan bertransaksi bagi konsumen. Perkembangan ini tentu 
harus dapat dipahami dengan baik oleh pelaku usaha toko online, dengan memenuhi apa yang dibutuhkan dan diharapkan konsumen, melalui aplikasi jual beli online dengan produk yang berkualitas, harga yang kompetitif, sistem transaksi yang handal, dan mekanisme pelayanan pelanggan yang terpadu. Persaingan sebagai sebuah keniscayaan harus dapat disikapi secara tepat, dengan merancang strategi pemasaran terbaik.

Toko online yang terus bermunculan menyebabkan terjadinya persaingan yang kompetitif antar toko online lainnya dalam hal menyediakan produk yang mampu mempertahankan konsumen loyal, salah satunya adalah melalui penyajian iklan di berbagai media, seperti yang terjadi antara Tokopedia, Bukalapak, Shopee, Lazada, dan lain sebagainya. Semakin bertambahnya jumlah konsumen yang tertarik untuk melakukan pembelian secara online, maka akan semakin banyak pula permintaan konsumen terhadap produk toko online. Dengan demikian toko online harus terus terus berinovasi agar tidak kehilangan pelanggan, mempertahankan eksistensi bisnisnya, dan bahkan menguasai pangsa pasar di pasar sasaran. Salah satu cara yang dapat dipilih perusahaan adalah dengan menciptakan iklan yang tepat dan didukung oleh endorser yang mampu menciptakan brand awareness secara positif.

Salah satu perusahaan yang bergerak di bidang bisnis toko online adalah PT Tokopedia yang sudah berdiri sejak 17 Agustus 2009 oleh William Tanuwijaya, dengan nama merek Tokopedia. Dalam menghadapi persaingan yang semakin ketat di bidang bisnis toko online, Tokopedia harus mampu menciptakan brand awareness yang kuat di benak konsumen, sehingga pada akhirnya konsumen tergerak untuk melakukan pembelian produk secara online di Tokopedia. Brand awareness atau kesadaran konsumen akan merek Tokopedia sebagai sebuah toko online, dapat dibentuk oleh berbagai faktor. Iklan dan endorser merupakan faktor yang diduga mampu secara signifikan membentuk brand awareness.

Dalam situasi di mana konsumen menyadari sejumlah merek yang sesuai dengan kriteria yang relevan, pembeli tidak mungkin menghabiskan banyak usaha dalam mencari informasi pada merek asing. Sebuah merek yang memiliki beberapa tingkat kesadaran merek adalah jauh lebih mungkin untuk dipertimbangkan, dan karena itu dipilih dari merek yang konsumen tidak menyadari. Selain itu, kekuatan kesadaran merek dalam pertimbangan juga dapat menjadi signifikan. Pentingnya pemikiran kesadaran dalam sebuah studi yang menemukan bahwa semakin tinggi posisi merek di benak konsumen diukur dengan penarikan kembali tanpa bantuan, semakin tinggi niat beli dan semakin tinggi pembelian relatif dari merek. Peningkatan kesadaran merek yang ditampilkan untuk meningkatkan kemungkinan pilihan bahkan tanpa ada perubahan yang menyertainya dalam sikap atau persepsi.

Berkaitan dengan hal tersebut brand awareness tentunya mempengaruhi keputusan pembelian dan konsumen juga tidak akan menghabiskan banyak waktu untuk membuat keputusan pembelian untuk merek yang belum diketahui. Sebuah kesadaran lebih lanjut menjelaskan cara merek dapat mempengaruhi pilihan dalam pertimbangkan kualitas merek toko online-nya. Semakin banyak konsumen yang terlibat dalam interaksi ritel online dan e-commerce berkembang pesat. Namun demikian pemahaman para cendekia tentang perilaku konsumen yang bertransaksi melalui media elektronik masih relatif terbatas ((Dennis, Merrilees, Jayawardhena, \& Tiu Wright, 2009); (Karimi, Papamichail, \& Holland, 2015). Hal ini disebabkan perilaku pembelian internet tidak selalu mengikuti perilaku pembelian konsumen tradisional. Ada beberapa upaya untuk memodelkan dan menafsirkan perilaku pembelian online (misalnya: (Chen \& Chang, 2003); (Darley, Blankson, \& Luethge, 2010); (Hsia, Wu, \& Li, 2008). Namun, masih ada kesenjangan tentang bagaimana individu yang berbeda terlibat dalam proses 
pengambilan keputusan pembelian dan bagaimana proses tersebut berlangsung yang terbentuk dari brand awareness.

\section{TINJAUAN PUSTAKA}

\section{Keputusan Pembelian Konsumen}

Setiap individu pasti memiliki cara pandang yang berbeda-beda, cara pandang tersebut mempengaruhi konsumen dalam pengambilan keputusan. Keputusan pembelian merupakan suatu proses psikologis yang dilalui oleh konsumen yang diawali dari tahap perhatian terhadap barang atau jasa yang ditawarkan, lalu tahap ketertarikan terhadap produk atau jasa tersebut, selanjutnya adalah tahap minat terhadap produk tersebut dan diakhiri dengan mengambil keputusan untuk membeli atau tidak (Solomon, 2014). Pengambilan keputusan konsumen merupakan sebuah proses pengintegrasian yang mengkombinasikan pengetahuan untuk mengevaluasi dua atau lebih perilaku alternatif dan memilih salah satu di antaranya ((Solomon, 2014); (Sumarwan, 2011)). Dengan demikian keputusan pembelian konsumen tidak dapat terlepas dari bagaimana konsumen melalui beberapa tahapan dalam proses pengambilan keputusannya, yaitu mengetahui masalah yang dihadapi sampai dengan terjadinya transaksi pembelian konsumen serta keputusan pembelian adalah tahap proses keputusan di mana konsumen secara aktual melakukan pembelian produk.

Terdapat empat model konsumen yang mempunyai cara pandang berbeda dalam pengambilan keputusan (Sumarwan, 2011), yaitu: (1) Manusia ekonomi, yakni manusia dipandang sebagai individu yang melakukan keputusan secara rasional; (2) Manusia pasif, menggambarkan manusia sebagai individu yang mementingkan diri sendiri dan menerima berbagai macam promosi yang ditawarkan pemasar; (3) Manusia kognitif, menggambarkan konsumen sebagai individu yang berfikir untuk memecahkan masalah; dan (4) Manusia emosional, menggambarkan konsumen sebagai individu yang memiliki perasaan mendalam dan emosi yang memperngaruhi pembelian atau pemilikan barangbarang tertentu.

Dalam konteks perilaku pembelian di dalam keluarga, ada lima peran yang dimainkan oleh pihak yang terkait dengan keputusan pembelian (Kotler \& Keller, 2009), yaitu:

1. Pencetus (initiator) yaitu orang yang pertama kali mengusulkan gagasan untuk membeli suatu produk atau jasa;

2. Pemberi pengaruh (influencer) yakni orang yang pandangan atau sarannnya mempengaruhi keputusan;

3. Pengambil keputusan (decider) yaitu orang yang mengambil keputusan untuk setiap konsumen keputusan pembelian (apakah membeli atau tidak, bagaimana dan di mana akan membeli);

4. Pembeli (buyer) yaitu orang yang melakukan pembelian yang sesungguhnya;

5. Pemakai (user) yaitu orang yang mengkonsumsi (menggunakan produk atau jasa yang bersangkutan)

\section{Brand Awareness}

Brand Awareness merupakan salah satu dimensi mendasar dari ekuitas merek, sering dianggap sebagai prasyarat dari keputusan pembelian konsumen, karena merupakan faktor utama termasuk merek pada keputusan pembelian (Keller, Parameswaran, \& Jacob, 2011). Brand dikembangkan tidak hanya melalui iklan, yang tak terhitung jumlahnya di media massa, atau dengan konfigurasi produk, harga, tempat/saluran distribusi, dan promosi. Brand dikenalkan melalui penerapan strategi, taktik, dan value yang tepat-kreatifitas dalam menentukan segmentasi dan strategi, pengembangan diferensiasi yang kuat ((Keller, 2003); (Keller et al., 2011)). 
Kesadaran merek (brand awareness) adalah kemampuan dari konsumen potensial untuk mengenali atau mengingat bahwa suatu merek termasuk ke dalam kategori produk tertentu(Keller et al., 2011). Kesadaran merek merupakan elemen ekuitas yang sangat

penting bagi perusahaan karena kesadaran merek dapat berpengaruh secara langsung terhadap ekuitas merek. Apabila kesadaran konsumen terhadap merek rendah, maka dapat dipastikan bahwa ekuitas mereknya juga akan rendah. Terdapat empat tingkatan terkait indikator dari brand awareness (Keller et al., 2011), yaitu:

1. Unaware of brand, konsumen masih merasa ragu atau tidak yakin apakah sudah mengenal merek yang disebutkan atau belum.

2. Brand recognition, konsumen mampu mengidentifikasi merek yang disebutkan.

3. Brand recall, konsumen mampu mengingat merek tanpa diberikan stimulus.

4. Top of mind, konsumen mengingat merek sebagai yang pertama kali muncul di pikiran saat berbicara mengenai kategori produk tertentu.

Brand awareness akan sangat berpengaruh terhadap ekuitas suatu merek. Kesadaran merek akan memengaruhi persepsi dan tingkah laku seorang konsumen. Oleh karena itu meningkatkan kesadaran konsumen terhadap merek merupakan prioritas perusahaan untuk membangun ekuitas merek yang kuat (Keller, 2003).

Brand awareness merupakan kemampuan pelanggan potensial untuk mengenali atau mengingat merek itu kembali bahwa suatu merek merupakan bagian dari kategori produk tertentu. Secara umum, kesadaran merek menggambarkan persepsi seseorang dan reaksi kognitif pada sebuah kondisi atau peristiwa. Kesadaran tidak memerlukan pemahaman penuh karena ia adalah sebuah konsep yang abstrak. Kesadaran bisa di fokuskan pada keadaan internal, seperti insting atau pada events eksternal seperti persepsi panca indera (Barreda, Bilgihan, Nusair, \& Okumus, 2015)

Mengacu pada pemahaman konseptual tersebut di atas, dapat disimpulkan bahwa kesadaran merek (brand awareness) adalah kesanggupan seorang pembeli untuk mengenali atau mengingat kembali bahwa suatu merek merupakan bagian dari kategori produk tertentu. Brand awareness juga akan menunjukkan pengetahuan konsumen terhadap eksistensi suatu brand di dalam benak konsumen.

\section{Iklan}

Kemampuan iklan untuk menciptakan sikap yang mendukung terhadap suatu produk mungkin sering bergantung pada sikap yang ditimbulkan dari iklan tersebut. iklan yang disukai atau dievaluasi secara menguntungkan dapat menghasilkan sikap yang positif terhadap produk, begitu pula sebaliknya akan menurunkan evaluasi produk oleh konsumen ketika iklan tersebut berkurang atau bahkan tidak disukai. Iklan merupakan struktur dan komposisi komunikasi informasi yang bersifat nonpersonal, umumnya dilakukan dengan berbayar yang dicirikan dengan persuasif, berisi tentang produk (barang, jasa, dan ide) yang diidentifikasikan sebagai sponsor melalui berbagai media. Dengan kata lain iklan adalah semua bentuk terbayar atas prestasi non pribadi dan promosi ide, barang atau jasa oleh sponsor yang jelas (Kotler \& Keller, 2009). Secara jelas, iklan merupakan suatu pesan persuasif untuk komunikasi pemasaran atau komunikasi publik tentang sesuatu produk (barang, jasa, atau ide) yang disampaikan melalui media, dibiayai oleh pemrakarsa serta ditujukan kepada sebagian atau seluruh masyarakat. Iklan juga sebagai bentuk komunikasi massa, di mana iklan terjadi bukan melalui proses tatap muka sebagaimana komunikasi interpersonal. Iklan dilakukan melalui medium, sebagaimana yang disebutkan di atas.

Tujuan dari iklan (Chen \& Chang, 2003), adalah sebagai berikut: 
1. Sebagai media informasi, ditujukan menginformasikan suatu produk barang dan jasa kepada khalayak.

2. Untuk mempengaruhi konsumen, yakni mengarahkan konsumen untuk mengkonsumsi produk barang atau jasa tertentu, atau mengubah sikap agar sesuai dengan apa yang diinginkan oleh pengiklan.

3. Untuk mengingatkan konsumen, iklan ditujukan agar konsumen selalu mengingat produk tertentu sehingga tetap setia mengkonsumsinya.

\section{Endorser}

Dalam periklanan dan kegiatan promosi lainnya, penggunaan sumber pesan untuk mengatakan atau memperlihatkan pesan iklan dapat dilakukan dengan cara memilih penyampai pesan yang dianggap dapat berpengaruh terhadap efektifitas komunikasi iklan. Endorser merupakan bentuk pernyataan bentuk ucapan mengenai suatu produk. Pesohor (celebrity) adalah seseorang baik sebagai artis, entertainer, atlet olahraga, maupun publik figur yang dikenal oleh masyarakat karena keahliannya di bidang tertentu. Endorser dapat diartikan sebagai orang yang terlibat dalam penyampaian pesan, dapat secara langsung ataupun tidak langsung, menggunakan ketenarannya untuk mempomosikan sebuah produk dan jasa (McCormick, 2016). Berdasarkan pengertian tersebut, dapat disimpulkan bahwa endorser adalah orang-orang yang menyampaikan pesan pada suatu iklan dan biasanya kita sebut orang-orang itu bintang iklan. Perusahaan biasanya memilih beberapa public figure, seperti bintang televisi, pemain film, atlet terkenal, penyanyi, dan orang-orang yang mempunyai prestasi lainnya yang secara luas digunakan pada iklan majalah, radio, spot dan iklan televisi untuk mendukung suatu produk (Kapitan \& Silvera, 2016).

Dalam keputusan pemilihan endorser, celebrity yang menjadi endorser harus dikenal banyak orang karena dapat mempengaruhi citra positif yang mencerminkan produknya sehingga pemilihan endorser yang tepat dalam iklan sangatlah penting. Beberapa indikator penting terkait endorser (Sääksjärvi, Hellén, \& Balabanis, 2016):

1. Kredibilitas (credibility), mengacu pada kecenderungan untuk percaya atau mempercayai endorser, terkait keahliannya dan kepercayaan terhadapnya

2. Daya tarik (attractiveness) terdiri dari tiga dimensi yang terkait kesamaan, keakraban, dan disukai. Daya tarik tidak hanya fisik, tapi juga meliputi sejumlah karakteristik yang menjadi kelebihan endorser, seperti keterampilan intelektual, sifat kepribadian, karakteristik gaya hidup, kecakapan dan sebagainya.

3. Kekuatan (power), kharisma yang dipancarkan oleh narasumber sehingga dapat mempengaruhi pemikiran, sikap, atau tingkah laku konsumen karena pernyataan atau pesan endorser tersebut.

\section{Hipotesis penelitian}

H1: Iklan dan endorser berpengaruh positif terhadap brand awareness.

$\mathrm{H} 2$ : Iklan berpengaruh positif terhadap brand awareness.

H3: Endorser berpengaruh positif terhadap brand awareness.

H4: Iklan, endorser, dan brand awareness bersama-sama berpengaruh positif terhadap keputusan pembelian.

H5: Iklan dan endorser berpengaruh positif terhadap keputusan pembelian.

H6: Iklan berpengaruh positif terhadap keputusan pembelian.

H7: Endorser berpengaruh positif terhadap keputusan pembelian.

$\mathrm{H} 8$ : Brand awareness berpengaruh positif terhadap keputusan pembelian. 


\section{METODE PENELITIAN}

Metode penelitian yang digunakan adalah analisis jalur yang merupakan pengembangan dari analisis regresi, sehingga analisis regresi dapat dikatakan sebagai bentuk khusus dari analisis jalur. Analisis jalur digunakan untuk menggambarkan dan menguji model hubungan antar variabel yang berbentuk sebab akibat, dengan demikian dalam model hubungan antar variabel tersebut, terdapat variabel independen, yang dalam hal ini disebut variabel eksogen dan variabel dependen yang disebut variabel endogen (Setiawan, 2015). Dalam menggunakan teknik analisis jalur, sebelumnya perlu diperinci operasionalisasi variabel penelitian, sebagaimana disajikan pada Tabel 1.

Tabel 1. Operasionalisasi Variabel

\begin{tabular}{|c|c|c|}
\hline Variabel & Indikator & Skala \\
\hline \multirow[t]{3}{*}{ Iklan $(\mathrm{X} 1)$} & 1. Mission & Ordinal \\
\hline & Message & \\
\hline & 3. Media & \\
\hline \multirow[t]{3}{*}{ Endorser (X2) } & 1. Credibility & Ordinal \\
\hline & 2. Attractiveness & \\
\hline & 3. Power & \\
\hline \multirow[t]{4}{*}{ Brand Awareness (Y) } & 1. Unaware of Brand & Ordinal \\
\hline & 2. Brand Recognition & \\
\hline & 3. Brand Recall & \\
\hline & 4. Top of Mind Awareness & \\
\hline \multirow{5}{*}{ Keputusan Pembelian (Z) } & 1. Pengenalan Masalah & Ordinal \\
\hline & 2. Pencarian Informasi & \\
\hline & 3. Evaluasi Alternatif & \\
\hline & 4. Keputusan Pembelian & \\
\hline & 5. Perilaku Pasca Pembelian & \\
\hline
\end{tabular}

Skala pengukuran yang digunakan untuk mengukur indikator-indikator pada variabel eksogen dan variabel endogen tersebut adalah dengan menggunakan Skala Likert (1-5). Skala ini termasuk dalam skala pengukuran ordinal (Setiawan, 2013) yang mempunyai lima tingkat preferensi jawaban masing-masing mempunyai skor 1-5:

5 = Sangat Setuju (SS)

$4=$ Setuju $(\mathrm{S})$

3 = Ragu-Ragu (R)

$2=$ Tidak Setuju (TS)

$1=$ Sangat Tidak Setuju (STS)

\section{HASIL DAN PEMBAHASAN}

\section{Karakteristik Responden}

Proporsi responden penelitian dari perspektif gender, terdiri dari responden pria sebesar $36 \%$ dan responden wanita sebesar $64 \%$. Apabila ditinjau dari perspektif sebaran usia, responden penelitian ini termasuk dalam kategori usia produktif, yakni antara 17 - 35 tahun, dengan dominasi responden berada pada rentang usia $21-25$ tahun sebanyak $63 \%$. Dominasi pekerjaan utama responden adalah mahasiswa $(51 \%)$ dan karyawan (29\%), dengan pendidikan formalnya adalah SMA/sederajat (54\%). Hal ini mengkonfirmasi data karakteristik sebaran usia responden yang berada pada kategori usia produktif. 
Indeks tanggapan responden akan indikator dari variabel iklan disajikan secara rinci pada Tabel 2, tanggapan akan indikator variable endorser disajikan pada Tabel 3, tanggapan akan indikator variable brand awareness disajikan pada Tabel 4, dan tanggapan akan indikator variable keputusan pembelian disajikan pada Tabel 5 .

Tabel 2. Indeks tanggapan responden akan indikator variabel iklan

\begin{tabular}{|c|c|c|c|c|c|c|c|c|}
\hline No & Pernyataan & 1 & 2 & 3 & 4 & 5 & Rata- Rata & Kategori \\
\hline 1 & $\begin{array}{l}\text { Iklan Tokopedia memberikan } \\
\text { informasi kepada saya }\end{array}$ & 0 & 1 & 17 & 63 & 19 & 4,00 & Setuju \\
\hline 2 & $\begin{array}{l}\text { Iklan Tokopedia membujuk saya } \\
\text { untuk membeli produk melalui } \\
\text { aplikasi online Tokopodia }\end{array}$ & 1 & 14 & 21 & 50 & 14 & 3,62 & Setuju \\
\hline 3 & $\begin{array}{l}\text { Iklan Tokopedia mengingatkan saya } \\
\text { akan canggihnya aplikasi online } \\
\text { Tokopedia }\end{array}$ & 0 & 5 & 9 & 68 & 18 & 3,99 & Setuju \\
\hline 4 & $\begin{array}{l}\text { Pesan iklan Tokopedia menarik } \\
\text { perhatian saya }\end{array}$ & 0 & 13 & 24 & 46 & 17 & 3,67 & Setuju \\
\hline 5 & $\begin{array}{l}\text { Daya tarik iklan Tokopedia } \\
\text { mendorong saya untuk langsung } \\
\text { menggunakan aplikasi }\end{array}$ & 1 & 20 & 22 & 46 & 11 & 3,46 & Setuju \\
\hline 6 & $\begin{array}{l}\text { Daya tarik pesan iklan Tokopedia } \\
\text { membngkitkan keinginan saya untuk } \\
\text { menggunakan aplikasi }\end{array}$ & 1 & 15 & 28 & 47 & 9 & 3,48 & Setuju \\
\hline 7 & $\begin{array}{l}\text { Iklan Tokopedia di setiap media } \\
\text { membuat saya ingin menggunakan } \\
\text { aplikasi Online Tokopedia }\end{array}$ & 0 & 20 & 36 & 36 & 8 & 3,32 & Ragu-Ragu \\
\hline 8 & $\begin{array}{l}\text { Gaya iklan Tokopedia yang } \\
\text { disampaikan di media apa saja, } \\
\text { menarik perhatian saya }\end{array}$ & 3 & 14 & 28 & 46 & 9 & 3,44 & Setuju \\
\hline 9 & $\begin{array}{l}\text { Keinginan saya untuk menggunakan } \\
\text { aplikasi online Tokopedia } \\
\text { dikarenakan media yang digunakan }\end{array}$ & 1 & 14 & 25 & 54 & 6 & 3,50 & Setuju \\
\hline & Rata - Rata & & & & & & 3,61 & Setuju \\
\hline
\end{tabular}

\section{Tabel 3. Indeks tanggapan responden akan indikator variabel endorser}

\begin{tabular}{clccccccc}
\hline No & \multicolumn{1}{c}{ Pernyataan } & 1 & 2 & 3 & 4 & 5 & Rata - Rata & Kategori \\
\hline 1 & $\begin{array}{l}\text { Endorser mengetahui kegunaan } \\
\text { aplikasi online }\end{array}$ & 2 & 6 & 28 & 50 & 14 & 3,68 & Setuju \\
\hline 2 & $\begin{array}{l}\text { Endorser dapat dipercaya saat } \\
\text { menyampaikan keunggulan } \\
\text { Tokopedia }\end{array}$ & 0 & 6 & 31 & 49 & 14 & 3,71 & Setuju \\
\hline 3 & Endorser berpengalaman & 0 & 7 & 23 & 14 & 56 & 4,19 & Setuju \\
\hline 4 & Penampilan Endorser menarik & 1 & 7 & 7 & 48 & 37 & 4,13 & Setuju \\
\hline 5 & $\begin{array}{l}\text { Endorser memiliki paras yang } \\
\text { mendukung iklan Tokopedia }\end{array}$ & 0 & 7 & 12 & 49 & 32 & 4,06 & Setuju \\
\hline 6 & $\begin{array}{l}\text { Endorser dalam iklan Tokopedia } \\
\text { terkenal di kalangan masyarakat }\end{array}$ & 1 & 4 & 26 & 41 & 28 & 3,91 & Setuju \\
\hline 7 & Endorser dapat menarik perhatian & 1 & 1 & 22 & 49 & 27 & 4,00 & Setuju \\
\hline 8 & $\begin{array}{l}\text { Endorser dapat mempengaruhi } \\
\text { pemikiran tentang Tokopedia }\end{array}$ & 2 & 5 & 29 & 45 & 19 & 3,74 & Setuju \\
\hline 9 & $\begin{array}{l}\text { Endorser mampu meyakinkan } \\
\text { konsumen akan Tokopedia }\end{array}$ & 0 & 6 & 34 & 45 & 15 & 3,69 & Setuju \\
\hline \multicolumn{1}{c}{ Rata - Rata } & & & & & 3,90 & Setuju \\
\hline
\end{tabular}


Budi Setiawan ${ }^{1)}$, Celia Celesta Rabuani ${ }^{2)}$, Pengaruh Iklan dan Endorser ...

Tabel 4.Indeks tanggapan responden akan indikator dari variabel brand awareness

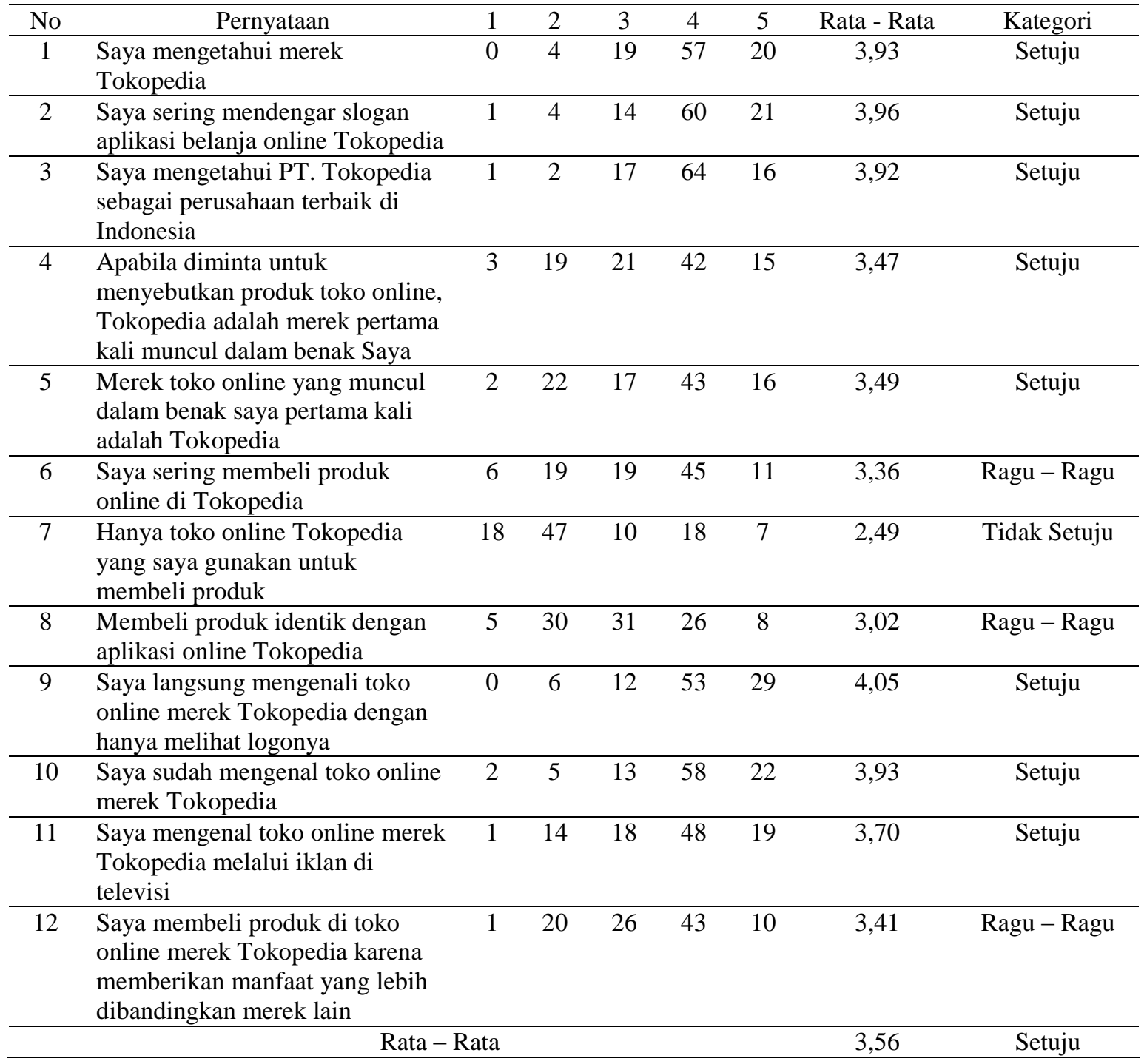

Tabel 5. Indeks tanggapan responden akan indikator dari variabel keputusan pembelian

\begin{tabular}{clccccccc}
\hline No & \multicolumn{1}{c}{ Pernyataan } & 1 & 2 & 3 & 4 & 5 & Rata - Rata & Kategori \\
\hline 1 & $\begin{array}{l}\text { Saya membutuhkan aplikasi } \\
\text { online Tokopedia untuk membeli } \\
\text { kebutuhan }\end{array}$ & 4 & 16 & 29 & 41 & 10 & 3,37 & Ragu - Ragu \\
\hline 2 & $\begin{array}{l}\text { Saya membutuhkan aplikasi } \\
\text { online Tokopedia untuk } \\
\text { memenuhi keinginan }\end{array}$ & 3 & 10 & 27 & 49 & 11 & 3,55 & Setuju \\
\hline 3 & $\begin{array}{l}\text { Saya menggunakan aplikasi } \\
\text { online Tokopedia karena } \\
\text { memiliki kepuasan tersendiri }\end{array}$ & 3 & 13 & 23 & 49 & 12 & 3,54 & Setuju \\
\hline 4 & $\begin{array}{l}\text { Saya memperoleh informasi } \\
\text { tentang aplikasi online Tokpedia } \\
\text { sebelum menggunakannya }\end{array}$ & 1 & 10 & 16 & 63 & 10 & 3,71 & Setuju \\
\hline 5 & $\begin{array}{l}\text { Sumber informasi aplikasi online } \\
\text { Tokopedia mudah didapatkan }\end{array}$ & 2 & 4 & 14 & 65 & 15 & 3,87 & Setuju \\
\hline 6 & $\begin{array}{l}\text { Saya bertanya kepada teman yang } \\
\text { menggunakan aplikasi online } \\
\text { Tokopedia tentang aplikasi ini }\end{array}$ & 1 & 14 & 18 & 55 & 12 & 3,63 & Setuju \\
\hline 7 & Saya mengevaluasi beberapa & 0 & 5 & 14 & 65 & 16 & 3,92 & Setuju \\
\hline
\end{tabular}


Riset: Jurnal Aplikasi Ekonomi, Akuntansi dan Bisnis Vol. 1 No. 1, Maret 2019, Hal 051 - 065

\begin{tabular}{|c|c|c|c|c|c|c|c|c|}
\hline & merek aplikasi online yang ada & & & & & & & \\
\hline 8 & $\begin{array}{l}\text { Aplikasi online Tokopedia } \\
\text { menjadi pilihan alternative yang } \\
\text { dipilih }\end{array}$ & 4 & 8 & 15 & 65 & 8 & 3,65 & Setuju \\
\hline 9 & $\begin{array}{l}\text { Berbelanja secara online } \\
\text { merupakan pilihan alternatif } \\
\text { untuk memenuhi kebutuhan }\end{array}$ & 4 & 3 & 13 & 64 & 16 & 3,85 & Setuju \\
\hline 10 & $\begin{array}{l}\text { Saya menggunakan aplikasi } \\
\text { online Tokopedia karena teruji } \\
\text { keamanannya }\end{array}$ & 1 & 1 & 22 & 58 & 18 & 3,91 & Setuju \\
\hline 11 & $\begin{array}{l}\text { Saya membeli produk melalui } \\
\text { aplikasi online Tokopedia karena } \\
\text { mudah digunakan }\end{array}$ & 1 & 6 & 11 & 66 & 16 & 3,90 & Setuju \\
\hline 12 & $\begin{array}{l}\text { Saya akan menggunakan aplikasi } \\
\text { online Tokopedia kembali }\end{array}$ & 2 & 2 & 20 & 59 & 17 & 3,87 & Setuju \\
\hline 13 & $\begin{array}{l}\text { Saya merasa puas setelah } \\
\text { melakukan pembelian melalui } \\
\text { aplikasi online Tokopedia }\end{array}$ & 2 & 4 & 18 & 59 & 17 & 3,85 & Setuju \\
\hline 14 & $\begin{array}{l}\text { Saya bersedia merekomendasikan } \\
\text { aplikasi online Tokopedia kepada } \\
\text { orang lain }\end{array}$ & 1 & 3 & 23 & 52 & 21 & 3,89 & Setuju \\
\hline 15 & $\begin{array}{l}\text { Karena sesuai dengan kebutuhan } \\
\text { dan keinginan maka saya akan } \\
\text { melakukan pembelian kembali }\end{array}$ & 3 & 4 & 21 & 60 & 12 & 3,74 & Setuju \\
\hline
\end{tabular}

\section{Hasil Analisis Jalur}

Hasil pengujian hipotesis untuk persamaan jalur 1 dan 2 disajikan pada Tabel 6.

Tabel 6. Hasil Uji Analisis Jalur

\begin{tabular}{lllcccccc}
\hline Model & $\begin{array}{l}\text { Variabel } \\
\text { Eksogen }\end{array}$ & $\begin{array}{c}\text { Variabel } \\
\text { Endogen }\end{array}$ & $\begin{array}{c}\text { Koefisien } \\
\text { Jalur }\end{array}$ & t-value & Sig. & F-value & Sig. & R Square \\
\hline Pers. & Iklan & Brand & 0,585 & 7,297 & 0,000 & 54,164 & 0,000 & 0,528 \\
Jalur I & Endorser & Awareness & 0,229 & 2,859 & 0,005 & & 0,000 & 0,000 \\
& Iklan & & 0,237 & 2,503 & 0,014 & & 0,000 & 0,579 \\
Pers. & Endorser & Keputusan & 0,108 & 1,367 & 0,175 & 44,011 & 0,000 & \\
Jalur II & Brand & Pembelian & 0,510 & 5,290 & 0,000 & & 0,000 \\
& Awareness & & & & & & & \\
\end{tabular}

Mengacu pada Tabel 6 dapat diketahui bahwa hasil persamaan jalur 1 yang digunakan untuk menganalisis pengaruh iklan dan endorser terhadap brand awareness menunjukan $\mathrm{R}^{2}$ sebesar 0,528. Hal ini berarti 52,8\% variabel brand awareness dapat dijelaskan oleh variabel iklan dan endorser. Sedangkan sisanya yaitu sebesar 47,2\% dijelaskan oleh variabel lain di luar yang diteliti.

Hasil uji signifikansi parameter parsial t menunjukan nilai t pada variabel iklan sebesar 7, $297>$ t tabel yakni 1,96, didukung dengan probabilitas signifikansi 0,000. Karena nilai probabilitas lebih kecil dari 0,05 maka dapat dikatakan variabel iklan secara langsung berpengaruh signifikan. Hal ini berarti bahwa variabel iklan berpengaruh terhadap brand awareness. Sedangkan nilai t pada variabel endorser sebesar 2,859 > t tabel yakni 1,96, didukung dengan probalitas signifikansi 0,005. Karena nilai probabilitas tersebut lebih kecil dari 0,05 maka dapat dikatakan variabel endorser secara langsung berpengaruh signifikan. Hal ini berarti bahwa variabel endorser berpengaruh terhadap brand awareness.

Hasil uji persamaan jalur 2 yang digunakan untuk melihat pengaruh iklan, endorser, brand awareness terhadap keputusan pembelian menunjukan nilai $\mathrm{R}^{2}$ sebesar 0,579 . Hal ini berarti $57,9 \%$ variabel keputusan pembelian dapat dijelaskan oleh variabel iklan, endorser, dan brand awareness. Sedangkan sisanya yaitu sebesar 42,1\% dijelaskan oleh 
variabel lain diluar yang diteliti. Hasil uji signifikansi parameter parsial t menunjukan nilai t pada variabel iklan sebesar 2,503 > t tabel 1,96, didukung dengan probabilitas signifikansi 0,014. Karena nilai probabilitas tersebut lebih kecil dari 0,05 maka dapat dikatakan variabel iklan secara langsung berpengaruh signifikan. Hal ini berarti bahwa variabel iklan berpengaruh terhadap keputusan pembelian. Nilai t pada variabel endorser sebesar 1,367 < t tabel 1,96, dengan probabilitas signifikansi 0,175. Karena nilai probabilitas tersebut lebih besar dari 0,05 maka dapat dikatakan variabel endorser tidak secara langsung berpengaruh signifikan. Hal ini berarti bahwa variabel endorser tidak berpengaruh langsung terhadap keputusan pembelian. Sedangkan nilai t pada variabel brand awareness sebesar 5,290 > t tabel 1,96, didukung dengan probabilitas signifikansi 0,000. Karena nilai probabilitas variabel brand awareness lebih kecil dari 0,05 maka dapat dikatakan secara langsung berpengaruh terhadap keputusan pembelian. Hal ini berarti bahwa variabel brand awareness berpengaruh terhadap keputusan pembelian.

Nilai signifikansi dari kedua variabel yaitu iklan $=0,000$ dan endorser $=0,005$ lebih kecil dari 0,05. Hasil ini memberikan kesimpulan bahwa variabel iklan dan endorser berpengaruh signifikan terhadap keputusan pembelian. Besarnya nilai $\mathrm{R}^{2}$ yang terdapat pada tabel adalah sebesar 0,528 , hal ini menunjukan bahwa kontribusi atau sumbangan pengaruh iklan dan endorser terhadap keputusan pembelian sebesar 52,8\% sementara sisanya 47,2\% merupakan kontribusi dari variabel - variabel lain yang tidak dimasukkan dalam penelitian. Sementara itu, untuk nilai $e_{1}$ dapat dicari dengan rumus $e_{1}=\sqrt{1-0,528}=0,687$. Nilai signifikansi dari ketiga variabel iklan $=0,014$, endorser $=0,175$, brand awarenessi $=0,000$ lebih kecil dari 0,05. Hasil ini memberikan kesimpulan bahwa iklan dan brand awareness berpengaruh signifikan terhadap keputusan pembelia, sedangkan variabel endorser tidak berpengaruh signifikan terhadap keputusan pembelian. Besarnya nilai $\mathrm{R}^{2}$ yang terdapat pada tabel adalah sebesar 0,579 , hal ini menunjukan kontribusi iklan, endorser, dan brand awareness terhadap keputusan pembelian adalah sebesar 57,9\% sementara sisanya 42,1\% merupakan kontribusi dari variabel - variabel lain yang diteliti. Sementara untuk nilai $e_{2}=\sqrt{1-0,579}=0,649$.

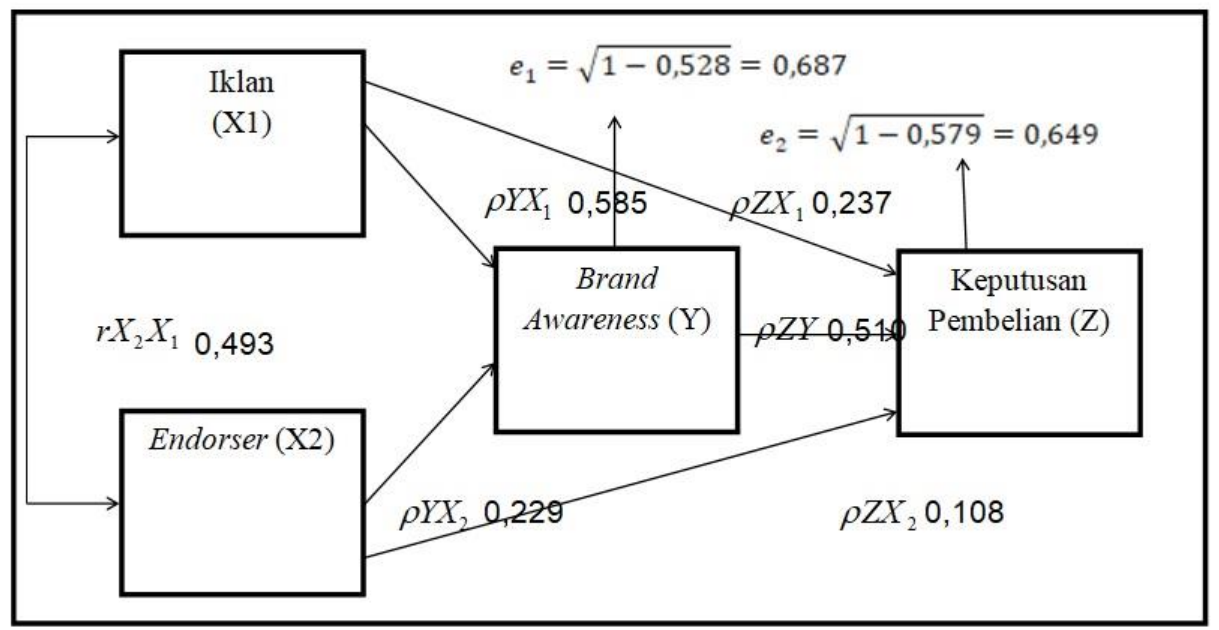

Gambar 1. Hasil Path Analysis

Mengacu pada Gambar 1, diketahui bahwa hubungan antar variabel iklan terhadap brand awareness memiliki nilai koefisien sebesar 0,585, sedangkan variabel endorser terhadap brand awareness memiliki nilai koefisien sebesar 0,229. Hubungan antar variabel iklan terhadap keputusan pembelian memiliki nilai koefisien sebesar 0,237, sedangkan variabel endorser terhadap keputusan pembelian memiliki nilai koefisien 
sebesar 0,108. Hubungan antar variabel brand awareness terhadap keputusan pembelian memiliki nilai koefisien sebesar 0,510. Hubungan anntar variabel iklan dengan endorser memilki nilai korelasi sebesar 0,493.

\section{Substruktur 1}

a. Menentukan hipotesis penelitian

Hipotesis secara simultan (keseluruhan) :

$\mathrm{H}_{0}$ : Iklan dan endorser secara silmutan tidak berpengaruh signifikan terhadap brand awareness.

$\mathrm{H}_{1}$ : Iklan dan endorser secara silmutan berpengaruh signifikan terhadap brand awareness.

Hipotesis secara parsial (individu) :

$\mathrm{H}_{0}$ : Iklan tidak berpengaruh signifikan terhadap brand awareness.

$\mathrm{H}_{1:}$ Iklan berpengaruh signifikan terhadap brand awareness.

$\mathrm{H}_{0:}$ Endorser tidak berpengaruh signifikan terhadap brand awareness.

$\mathrm{H}_{2}$ : Endorser berpengaruh signifikan terhadap brand awareness.

b. Membangun persamaan struktural

$$
\hat{Y}=\rho Y X_{1}+\rho Y X_{2}+e
$$

c. Lakukan teknik analisis jalur (path analysis) dengan memasukan data variabel eksogen Iklan dan Endorser ke dalam kotak Independent(s), dan masukan data variabel endogen Brand Awareness ke dalam kotak Dependent. Hasilnya secara rinci disajikan pada Tabel 7, Tabel 8, dan Tabel 9.

Tabel 7. Model Summary

\begin{tabular}{lllll}
\hline Model & $\mathrm{R}$ & $\mathrm{R}$ Square & Adjusted R Square & Std. Error of the Estimate \\
\hline 1 & $.726^{\mathrm{a}}$ & .528 & .518 & 4.81466 \\
\hline a. Predictors: (Constant), X2, X1 & & &
\end{tabular}

Tabel 8. ANOVA ${ }^{\mathrm{a}}$

\begin{tabular}{llrrrrr}
\hline Model & & Sum of Squares & df & Mean Square & F & \multicolumn{1}{c}{ Sig. } \\
\hline 1 & Regression & 2511.159 & 2 & 1255.580 & 54.164 & $.000^{\mathrm{b}}$ \\
& Residual & 2248.551 & 97 & 23.181 & & \\
& Total & 4759.710 & 99 & & & \\
\hline
\end{tabular}

a. Dependent Variable: Y1

b. Predictors: (Constant), X2, X1

Tabel 9. Coefficients ${ }^{\mathrm{a}}$

\begin{tabular}{|c|c|c|c|c|c|c|}
\hline \multirow{2}{*}{\multicolumn{2}{|c|}{ Model }} & \multicolumn{2}{|c|}{ Unstandardized Coefficients } & Standardized Coefficients & \multirow[b]{2}{*}{$\mathrm{t}$} & \multirow[b]{2}{*}{ Sig. } \\
\hline & & B & Std. Error & Beta & & \\
\hline 1 & (Constant) & 10.276 & 3.286 & & 3.127 & .002 \\
\hline & $\mathrm{X} 1$ & .709 & 097 & .585 & 7.297 & .000 \\
\hline & $\mathrm{X} 2$ & .272 & .095 & .229 & 2.859 & .005 \\
\hline
\end{tabular}

a. Dependent Variable: Y1

Mengacu pada output tabel ANOVA, diketahui bahwa nilai signifikan (Sig.) uji F 0,000 $<0,05$ sehingga $\mathrm{H}_{0}$ pada hipotesis silmutan ditolak. Interpretasinya adalah bahwa secara simultan (bersama - sama / keseluruhan) Iklan dan Endorser berpengaruh signifikan terhadap brand awareness. Mengacu pada output tabel model summary diketahui bahwa secara simultan Iklan dan Endorser mampu menjelaskan Brand awareness sebesar 52,8\% (nilai $R$ Square x 100\%). Mengacu pada output tabel coefficients, maka pada uji hipotesis secara parsial melalui uji t diketahui bahwa Iklan berpengaruh 
signifikan terhadap Brand Awareness sebesar 0,585. Demikian pula dengan Endorser yang berpengaruh signifikan terhadap Brand Awareness sebesar 0,229.

Persamaan matematika model substruktur 1 yang diperoleh adalah sebagai berikut:

$$
\hat{Y}=0,585 X_{1}+0,229 X_{2}
$$

\section{Substruktur 2}

a. Menentukan hipotesis penelitian

Hipotesis secara simultan (keseluruhan) :

$\mathrm{H}_{0}$ : Iklan, endorser, dan brand awareness secara simultan tidak berpengaruh signifikan terhadap keputusan pembelian.

$\mathrm{H}_{1}$ : Iklan, endorser,dan brand awareness secara simultan berpengaruh signifikan terhadap keputusan pembelian.

$\mathrm{H}_{0}$ : Iklan dan endorser secara simultan tidak berpengaruh signifikan terhadap keputusan pembelian.

$\mathrm{H}_{2}$ : Iklan dan endorser secara simultan berpengaruh signifikan terhadap keputusan pembelian.

Hipotesis secara parsial (individu) :

$\mathrm{H}_{0}$ : Iklan tidak berpengaruh signifikan terhadap keputusan pembelian.

$\mathrm{H}_{1}$ : Iklan tidak berpengaruh signifikan terhadap keputusan pembelian.

$\mathrm{H}_{0}$ : Endorser tidak berpengaruh signifikan terhadap keputusan pembelian.

$\mathrm{H}_{2}$ : Endorser tidak berpengaruh signifikan terhadap keputusan pembelian.

$\mathrm{H}_{0}$ : Brand Awareness tidak berpengaruh signifikan terhadap keputusan pembelian.

$\mathrm{H}_{3}$ : Brand Awareness tidak berpengaruh signifikan terhadap keputusan pembelian.

a. Membangun persamaan struktural

$$
\hat{Z}=\rho Z X_{1}+\rho Z X_{2}+\rho Z Y+e
$$

b. Lakukan teknik analisis jalur (path analysis) dengan memasukan data variabel eksogen Iklan, Endorser. dan Brand Awareness ke dalam kotak Independent( $(s)$, dan masukan data variabel endogen Keputusan Pembelian ke dalam kotak Dependent. Hasilnya tampak pada Tabel 10, Tabel 11, dan Tabel 12.

Tabel 10. Model Summary

\begin{tabular}{lllll}
\hline Model & R & R Square & Adjusted R Square & Std. Error of the Estimate \\
\hline 1 & $.761^{\text {a }}$ & .579 & .566 & 5.62487 \\
\hline a. Predictors: (Constant), Y1, X2, X1 & &
\end{tabular}

Tabel 11. ANOVAa

\begin{tabular}{llrrrrr}
\hline Model & & Sum of Squares & df & Mean Square & F & \multicolumn{1}{c}{ Sig. } \\
\hline 1 & Regression & 4177.395 & 3 & 1392.465 & 44.011 & $.000^{\mathrm{b}}$ \\
& Residual & 3037.355 & 96 & 31.639 & & \\
& Total & 7214.750 & 99 & & & \\
\hline
\end{tabular}

a. Dependent Variable: Z1

b. Predictors: (Constant), Y1, X2, X1

\begin{tabular}{|c|c|c|c|c|c|c|}
\hline \multirow[b]{2}{*}{ Model } & & \multicolumn{2}{|c|}{ Unstandardized Coefficients } & $\begin{array}{l}\text { Standardized } \\
\text { Coefficients }\end{array}$ & \multirow[b]{2}{*}{$\mathrm{t}$} & \multirow[b]{2}{*}{ Sig. } \\
\hline & & $\mathrm{B}$ & Std. Error & Beta & & \\
\hline 1 & (Constant) & 12.472 & 4.028 & & 3.097 & .003 \\
\hline & $\mathrm{X} 1$ & .354 & .141 & .237 & 2.503 & .014 \\
\hline & $\mathrm{X} 2$ & .158 & .116 & .108 & 1.367 & .175 \\
\hline & Y1 & .627 & .119 & .510 & 5.290 & .000 \\
\hline
\end{tabular}

Tabel 12. Coefficients ${ }^{\mathrm{a}}$ 
Mengacu pada output tabel ANOVA, diketahui bahwa nilai signifikan (Sig.) uji F 0,000 $<0,05$ sehingga $\mathrm{H}_{0}$ pada hipotesis simultan ditolak. Interpretasinya adalah bahwa secara simultan (bersama - sama / keseluruhan) Iklan, Endorser, dan Brand Awareness berpengaruh signifikan terhadap Keputusan Pembelian. Mengacu pada output tabel model summary diketahui bahwa secara simultan Iklan, Endorser, dan Brand Awareness mampu menjelaskan Keputusan Pembelian sebesar 57,8\% (nilai $R$ Square $\mathrm{x}$ $100 \%$ ). Mengacu pada output tabel coefficients, maka pada uji hipotesis secara parsial melalui uji $\mathrm{t}$ diketahui bahwa Iklan berpengaruh signifikan terhadap Keputusan Pembelian sebesar 0,237. Mengacu pada tabel coefficients, maka pada uji hipotesis secara parsial melalui uji t diketahui bahwa Endorser tidak berpengaruh signifikan terhadap Keputusan Pembelian sebesar 0,108. Demikian pula dengan Brand Awareness yang berpengaruh signifikan terhadap Keputusan Pembelian sebesar 0,510.

a. Persamaan matematika model substruktur 2

$$
\hat{Z}=0,237 X_{1}+0,108 X_{2}+0,510 Y
$$

b. Korelasi antara variabel eksogen Iklan dan Endorser

c. Peneliti menggunakan teknik analisis korelasi bivariate Pearson. Hasilnya tampak pada Tabel 13.

Tabel 13. Correlations (Pengikat Jalur Path Analysis)

\begin{tabular}{llrrrr}
\hline & & X1 & \multicolumn{1}{c}{ X2 } & \multicolumn{1}{c}{ Y1 } & \multicolumn{1}{c}{ Z1 } \\
\hline X1 & Pearson Correlation & 1 & 0,493 & 0,698 & 0,646 \\
& Sig. (2-tailed) & & .000 & .000 & .000 \\
& N & 100 & 100 & 100 & 100 \\
X2 & Pearson Correlation & 0,493 & 1 & 0,518 & 0,489 \\
& Sig. (2-tailed) & .000 & & .000 & .000 \\
& N & 100 & 100 & 100 & 100 \\
Y1 & Pearson Correlation & 0,698 & 0,518 & 1 & 0,731 \\
& Sig. (2-tailed) & .000 & .000 & & .000 \\
& N & 100 & 100 & 100 & 100 \\
Z1 & Pearson Correlation & 0,646 & 0,489 & 0,731 & 1 \\
& Sig. (2-tailed) & .000 & .000 & .000 & \\
& N & 100 & 100 & 100 & 100 \\
& & & & & \\
\hline
\end{tabular}

Pengaruh langsung yang diberikan iklan terhadap keputusan pembelian sebesar 0,237. Sedangkan pengaruh tidak langsung iklan melalui brand awareness terhadap keputusan pembelian adalah perkalian antara nilai beta iklan terhadap brand awareness dengan nilai beta brand awareness terhadap keputusan pembelian yaitu :0,585 x 0,510 =0,298. Maka pengaruh total yang diberikan iklan terhadap keputusan pembelian adalah pengaruh langsung ditambah dengan pengaruh tidak langsung yaitu : 0,237 $+0,298=$ 0,535. Berdasarkan hasil perhitungan di atas ketahui bahwa nilai pengaruh langsung sebesar 0,237 dan pengaruh tidak langsung sebesar 0,298 yang berarti bahwa nilai pengaruh tidak langsung lebih besar dibandingkan dengan nilai pengaruh langsung, hasil ini menunjukan bahwa secara tidak langsung iklan melalui brand keputusan mempunyai pengaruh signfikan terhadap keputusan pembelian.

Pengaruh langsung yang diberikan endorser terhadap keputusan pembelian sebesar 0,108. Sedangkan pengaruh tidak langsung endorser melalui brand awareness terhadap keputusan pembelian adalah perkalian antara nilai beta endorser terhadap brand awareness dengan nilai beta brand awareness terhadap keputusan pembelian yaitu $: 0,229 \times 0,510=0,117$. Maka pengaruh total yang diberikan endorser terhadap 
Budi Setiawan ${ }^{1)}$, Celia Celesta Rabuani ${ }^{2)}$, Pengaruh Iklan dan Endorser ...

keputusan pembelian adalah pengaruh langsung ditambah dengan pengaruh tidak langsung yaitu : $0,108+0,117=0,225$. Berdasarkan hasil perhitungan di atas ketahui bahwa nilai pengaruh langsung sebesar 0,108 dan pengaruh tidak langsung sebesar 0,117 yang berarti bahwa nilai pengaruh tidak langsung lebih besar dibandingkan dengan nilai pengaruh langsung, hasil ini menunjukan bahwa secara tidak langsung iklan melalui brand keputusan mempunyai pengaruh signfikan terhadap keputusan pembelian.

\section{SIMPULAN}

Simpulan dari hasil penelitian ini adalah sebagai berikut:

1. Iklan dan Endorser berpengaruh positif dan signifikan terhadap Brand Awareness. Penelitian ini menunjukan bahwa iklan dan endorser berpengaruh secara langsung terhadap brand awareness.

2. Iklan berpengaruh positif dan signifikan terhadap Brand Awareness. Penelitian ini menemukan bahwa iklan berpengaruh secara langsung terhadap Brand Awareness. Semakin tinggi tingkat pengaruh iklan maka semakin terbentuk pula tingkat Brand Awareness pada konsumen.

3. Endorser berpengaruh positif dan signifikan terhadap brand awareness. Penelitian ini menemukan bahwa endorser berpengaruh secara langsung terhadap brand awareness. Semakin tinggi tingkat pengaruh endorser maka semakin terbentuk pula tingkat brand awareness.

4. Iklan, Endorser, dan Brand Awareness memiliki pengaruh langsung terhadap Keputusan Pembelian melalui Brand Awareness. Penelitian ini menunjukkan bahwa iklan berpengaruh terhadap brand awareness, namun brand awareness tidak berpengaruh terhadap keputusan pembelian. Hal ini berarti bahwa brand awareness tidak memediasi hubungan iklan dan keputusan pembelian.

5. Iklan dan Endorser memiliki pengaruh langsung terhadap Keputusan Pembelian. Penelitian ini menunjukkan bahwa iklan dan endorser berpengaruh terhadap keputusan pembelian.

6. Iklan berpengaruh positif dan signifikan terhadap keputusan pembelian. Variabel iklan berpengaruh langsung terhadap keputusan pembelian.

7. Endorser tidak berpengaruh positif dan signifikan terhadap keputusan pembelian. Penelitian ini menunjukan bahwa endorser tidak berpengaruh secara langsung kepada keputusan pembelian konsumen.

8. Brand awareness berpengaruh secara langsung terhadap keputusan pembelian. Penelitian ini menemukan bahwa brand awareness berpengaruh positif dan signifikan terhadap keputusan pembelian. Semakin tinggi tingkat pengaruh brand awareness maka semakin tinggi

\section{DAFTAR PUSTAKA}

Barreda, A. A., Bilgihan, A., Nusair, K., \& Okumus, F. (2015). Generating brand awareness in Online Social Networks. Computers in Human Behavior, 50, 600609. https://doi.org/10.1016/j.chb.2015.03.023

Chen, S. J., \& Chang, T. Z. (2003). A descriptive model of online shopping process: Some empirical results. International Journal of Service Industry Management, 556-569. https://doi.org/10.1108/09564230310500228

Darley, W. K., Blankson, C., \& Luethge, D. J. (2010). Toward an integrated framework for online consumer behavior and decision making process: A review. Psychology and Marketing, 27(2), 94-116. https://doi.org/10.1002/mar.20322

Dennis, C., Merrilees, B., Jayawardhena, C., \& Tiu Wright, L. (2009). E- consumer 
Hsia, T. L., Wu, J. H., \& Li, E. Y. (2008). The e-commerce value matrix and use case model: A goal-driven methodology for eliciting B2C application requirements. Information and Management, 45(5), 321-330. https://doi.org/10.1016/j.im.2008.04.001

Kapitan, S., \& Silvera, D. H. (2016). From digital media influencers to celebrity endorsers: attributions drive endorser effectiveness. Marketing Letters, 27(3), 553567. https://doi.org/10.1007/s11002-015-9363-0

Karimi, S., Papamichail, K. N., \& Holland, C. P. (2015). The effect of prior knowledge and decision-making style on the online purchase decision-making process: A typology of consumer shopping behaviour. Decision Support Systems, 77, 137147. https://doi.org/10.1016/j.dss.2015.06.004

Keller, K. L. (2003). Brand Synthesis: The Multidimensionality of Brand Knowledge. Journal of Consumer Research, 29(4), 595-600. https://doi.org/10.1086/346254

Keller, K. L., Parameswaran, M. G., \& Jacob, I. (2011). Strategic brand management: Building, measuring, and managing brand equity. Pearson Education India.

Kotler, P., \& Keller, K. L. (2009). Manajemen pemasaran (edisi 12). Jakarta: Erlangga.

McCormick, K. (2016). Celebrity endorsements: Influence of a product-endorser match on Millennials attitudes and purchase intentions. Journal of Retailing and Consumer Services, 32, 39-45. https://doi.org/10.1016/j.jretconser.2016.05.012

Sääksjärvi, M., Hellén, K., \& Balabanis, G. (2016). Sometimes a celebrity holding a negative public image is the best product endorser. European Journal of Marketing, 50(3/4), 421-441. https://doi.org/10.1108/EJM-06-2014-0346

Setiawan, B. (2013). Menganalisa Statistik Bisnis dan Ekonomi dengan SPSS 21. Yoyakarta: CV Andi Offset.

Setiawan, B. (2015). Teknik Praktis Analisis Data Penelitian Sosial \& Bisnis dengan SPSS. Yogakarta: CV Andi Offset.

Solomon, M. R. (2014). Consumer Behavior (Global Edi). Pearson Education Limited. Sumarwan, U. (2011). Perilaku konsumen: Teori dan penerapannya dalam pemasaran. Bogor: Ghalia Indonesia. 